\title{
Population dynamics and secondary production of Euzonus furciferus Ehlers (Polychaeta, Opheliidae) in an exposed sandy beach of Southern Brazil
}

\author{
José R. B. de Souza ${ }^{1} \&$ Carlos A. Borzone ${ }^{2}$ \\ ${ }^{1}$ Departamento de Zoologia, Centro de Ciências Biológicas, Universidade Federal de Pernambuco. Avenida Professor Nelson \\ Chaves 235, 50670-420 Recife, Pernambuco, Brasil. E-mail: jrbsouza@ufpe.br \\ ${ }_{2}^{2}$ Centro de Estudos do Mar, Universidade Federal do Paraná. Avenida Beira Mar, Pontal do Sul, 83255-000 Pontal do \\ Paraná, Brasil. E-mail: capborza@ufpr.br
}

\begin{abstract}
The distribution, population dynamics and secondary production of the polychaete Euzonus furciferus was studied in Atami Beach (Southern Brazil), from February 1992 to March 1993. Euzonus furciferus Ehlers, 1897 is the only deposit feeder species of the upper intertidal region. The organisms were present in the sandy beach all over the year, concentrated in a narrow band, and reaching maximal densities of 3,029 individuals $\mathrm{m}^{-2}$. Peaks of abundance occurred in September 1992, with a mean of 681.8 individuals $\mathrm{m}^{-2}$. Recruitment occurred in winter, with a peak in July. Mean annual biomass was estimated in $0.218 \mathrm{gAFDW} \mathrm{m}^{-2}$, with a total annual production of 0.466 gAFDW $\mathrm{m}^{-2} \mathrm{y}^{-1}$, giving a P/B ratio of $2.13 \mathrm{y}^{-1}$. Similar values were found for a filter-feeder polychaete inhabiting the same beach, suggesting that general food disposability of each particular environment is more important for production than the trophic strategic employed by those organisms exploring this environment. KEY WORDS. Annelida; benthos; deposit feeder; intertidal; macrofauna.
\end{abstract}

\begin{abstract}
RESUMO. Dinâmica populacional e produção secundaria de Euzonus furciferus Ehlers (Polychaeta, Opheliidae) numa praia exposta do sul do Brasil. A dinâmica populacional e a produção secundária do poliqueta Euzonus furciferus foi estudada em uma praia arenosa exposta do sul do Brasil. O estudo foi realizado na praia de Atami, de fevereiro de 1992 a março de 1993. Euzonus furciferus Ehlers, 1897 é a única espécie comedora de depósito da região superior do intermareal. Os organismos foram encontrados na praia ao longo de todo o ano, concentrados em uma estreita faixa, e alcançando densidades máximas de 3.029 indivíduos. $\mathrm{m}^{-2}$. Picos de abundância ocorreram em setembro de 1992, com uma média de 681,8 indivíduos. $\mathrm{m}^{-2}$. O recrutamento ocorreu no inverno, com um pico em julho. A biomassa média anual foi estimada em 0,218 gPSLC m² ${ }^{-2}$ com uma produção anual total de 0,466 gPSLC m² ano-1 $^{-1}$ e com uma razão P/B de 2,13 ano-1. Valores similares foram encontrados para um poliqueta filtrador existentes na mesma praia, sugerindo que a disponibilidade geral de alimento para cada ambiente particular é mais importante para a produção do que a estratégia trófica empregada pelos organismos que exploram este ambiente.
\end{abstract}

PALAVRAS-CHAVE. Annelida; bentos; detritívoro; intermareal; macrofauna.

Polychaetes belonging Opheliidae Maimgren, 1867, family are burrowers in sandy or muddy sediments, and usually classify as non-selective deposit-feeders (FAUChald \& Jumars 1979). Organic-rich sediments characteristics of tidal flats are typically inhabit by this polychaetes, although at least four genera, Ophelia Savigny, 1818, Thoracophelia Ehlers, 1897 (=Euzonus Grube, 1866), Armandia Filippi, 1861 and Travisia Johnston, 1840 may occurred in the organic poor sediments of high energy sandy beaches (McLachlan \& Brown 2006).

At present, 15 species of genus Euzonus are known, and most of them inhabit intertidal sandy beaches (SANTOS et al. 2004). Euzonus furciferus Ehlers, 1897 was originally described from Strait of Magellan, and reported, with doubts, from Uru- guay to Rio Grande do Sul by Orensanz \& Gianuca (1974). Recently, SANTOS et al. (2004) found that, although similar, this species probably is not E. furciferus. In the present work, we named all the southern Brazilian material as E. furciferus until a future revision define the taxonomic status of this species.

Euzonus furciferus has a well-defined distribution in the upper intertidal of sub-tropical Brazilian sandy beaches, from reflective to dissipative ones (Gianuca 1987, Souza \& Gianuca 1995, Borzone et al. 1996, Barros et al. 2001). This species is also common in the highest level of the middle shore of Uruguayan beaches (Escofet et al. 1979, Defeo et al. 1992).

In spite of its constant presence in this important coastal environment, poorly is known about its biology at this sub- 
tropical region. The aim of the present study was to describe the population dynamics and secondary production of this species in a southern Brazilian sandy beach.

\section{MATERIAL AND METHODS}

The littoral of Paraná State includes some Atlantic open to the ocean beaches. Southern the inlet of Paranaguá Bay estuarine system, the Estearn Coastal Plain comprises a sandy beach with variable sandy sediment and morphological characteristics throughout its extension. Atami Beach $\left(25^{\circ} 20^{\prime} \mathrm{S} ; 48^{\circ} 05^{\prime} \mathrm{W}\right)$ is the first beach $10 \mathrm{~km}$ south of Paranaguá Bay inlet. Sampling was undertaken in thirteen stations distributed along a transect at $15 \mathrm{~m}$ intervals in the intertidal beach, and $30 \mathrm{~m}$ intervals in the subtidal beach, from the beginning of the vegetation to nearly $3 \mathrm{~m}$ deep, and from February 1992 to March 1993. Triplicate macrofaunal samples were collected at each station with an iron core of $0.05 \mathrm{~m}^{2}$, taken to a depth of $25 \mathrm{~cm}$, during low tides. Sand was sieved with a $0.5 \mathrm{~mm}$ mesh and organisms fixed in formalin $10 \%$. Sediment samples were collected for standard mechanical-sieving grain size analysis. Mean and standard deviation were computed according to Moments Method (TANNER 1995) and results expressed as $\phi$ values $\left(\phi=-\log _{2}\right.$ diameter in $\mathrm{mm})$. Beach slope, surf water salinity and temperature and wave height and period were measured each month. Modal morphodynamic states were computed employing the dimensionless fall velocity parameter, according with MASSELINK \& SHORT 1993 (Borzone \& Souza 1997).

Body width of each individual of $E$. furciferus was measure at chaetiger $8^{\text {th }}$ and this measure was used as length for growth calculation. The whole body was first dried in an oven at $80^{\circ} \mathrm{C}$ until reach constant weight, and after that it was burned at $500^{\circ} \mathrm{C}$ in a mufle oven by 24 hours to estimate de ash free dry weight (AFDW).

The growth parameters were estimated by fitting the seasonalized von Bertalanffy growth function (sVBGF) (PAulY \& GASCHUTZ 1979):

$$
L_{t}=L_{\infty}\left[1-e^{\left[-K\left(t-t_{0}\right)\right]+(K C / 2 \pi) \operatorname{sen}\left(2 \pi\left(t-t_{s}\right)\right)-(K C / 2 \pi) \operatorname{sen}\left(2 \pi\left(t_{0}-t_{s}\right)\right)}\right]
$$

where: $L_{t}=$ length at age $t ; L_{\infty}=$ maximum asymptotic length; $\mathrm{k}$ = growth curve parameter; $\mathrm{t}_{\mathrm{o}}=$ computed age at length zero; $\mathrm{C}=$ parameter reflecting the intensity of seasonal oscillation; $\mathrm{t}_{\mathrm{s}}=$ start of a sinusoid growth oscillation with respect to $\mathrm{t}=0$. The growth parameters were estimated in two steps: (1) preliminary estimates of $\mathrm{L}_{\infty}$ were obtained by the method of Wetherall (1986) as modified by Pauly (1986), and (2) this estimated $\mathrm{L}_{\infty}$ was the used as a 'seeded' value for fitting a growth curve to the length-frequency data. Total mortality $\mathrm{Z}$ was calculated by the single negative exponential model, using the method of length-converted catch curve of the ELEFAN II routine (Gayanillo et al. 1996). The analysis of the different cohorts was done using the BHATTACHARYa (1967) method through the routine NORMSEP (GAYANILO et al. 1996).
Annual somatic production was calculated using mass specific growth rate method (MSGR) described by CRISP (1984). This method uses the size-frequency distribution, the size growth function and the size-body mass relation. Production was computed by: $P_{s}=\Sigma N_{i} \times M_{i} \times G_{i}$, where $N_{i}$ is the number of individuals in size class $i, M_{i}$ is the mean individual body mass in size class $i$, and $G_{i}$ is the corresponding mass-specific growth rate obtained from VBGF parameters, and the size-mass relation.

\section{RESULTS}

During the sampling period, salinity at the surf zone ranged from 29.9 (in June) to 33.8 (in November) and temperature from $17^{\circ} \mathrm{C}$ (in July) to $29.2^{\circ} \mathrm{C}$ (in January), the last with a characteristic seasonal subtropical variation. The beach presented most of the time a gentle slope, about one degree, with a slight increase probably associated with a constructive period during summer months (January, February and March). Sediment was composed of fine to very fine sands, with an average of $2.90 \phi(0.134 \mathrm{~mm})$. Omega values used to classify morphodynamics states varied from intermediate (2.6 to 4.3) during some spring and summer months to dissipative (5.1 to 12.4) in the remainder months (Tab. I).

The organisms were found in a narrow band ( $\pm 30 \mathrm{~m}$ wide) parallel to shore, in the upper to mid intertidal beach (Fig. 1).

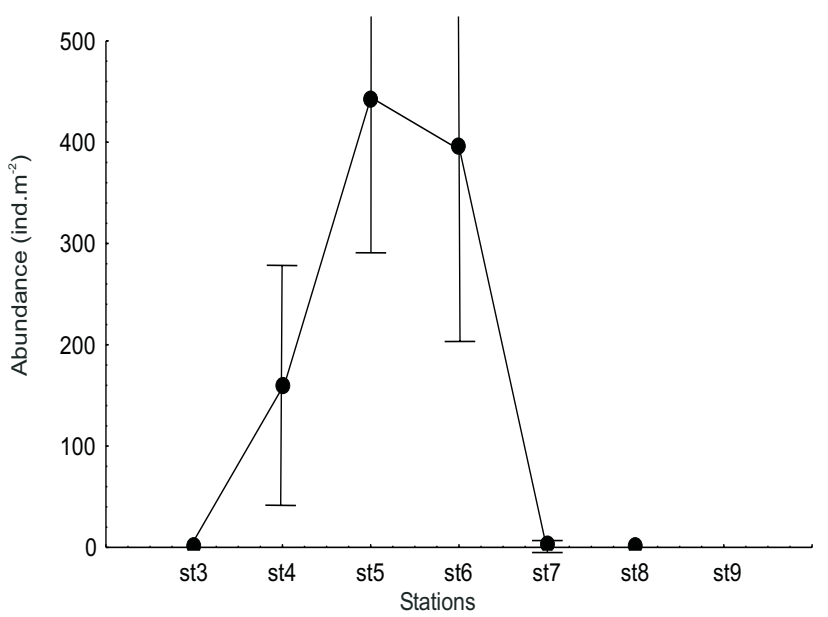

Figure 1. Distribution of Euzonus furciferus along the transect at 15 $m$ intervals (monthly mean \pm standard error).

Monthly abundance varied from 41 individuals.m ${ }^{-2}$ (in March 93), to 682 individuals. $\mathrm{m}^{-2}$ (in September), with higher densities in fall and winter months (April to September) than in summer months (October to January). Euzonus furciferus, in September, showed a high abundance and low individual biomass, whereas this last one showed high values in May (Figs 2 and 3). 

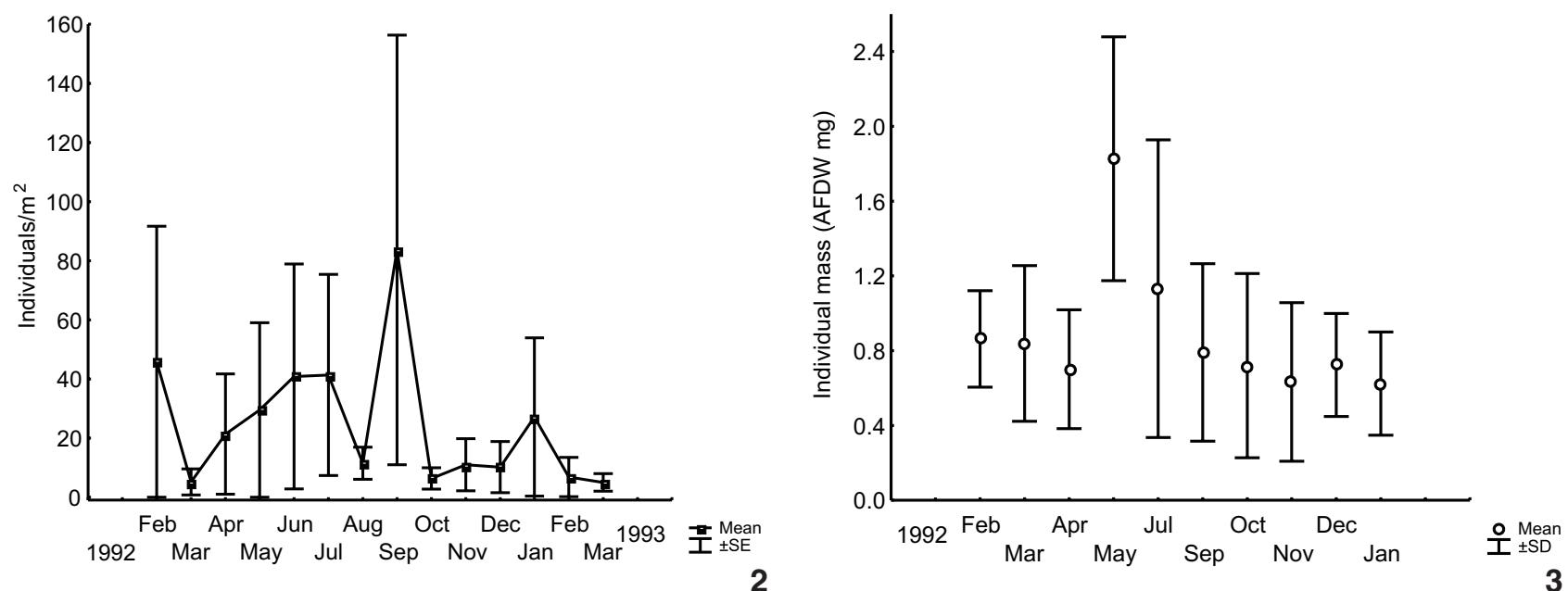

Figures 2-3. Abundance $/ \mathrm{m}^{2}$ (2) and (3) mean individual mass AFDW (mg) of Euzonus furciferus at Atami Beach from February 1992 to March 1993.

Table I. Monthly physical parameters and morphodynamics characteristics of Atami Beach from February 1992 to March 1993. (T) Water temperature, $(S)$ water salinity, $(\mathrm{Hb})$ breaker wave height, $(\mathrm{P})$ breaker wave period, $(\mathrm{Md})$ beach face mean grain size, $(\Omega)$ "Dean" parameter, ( $\beta B F)$ beach face slope. From BORzOne \& SOUZA (1997).

\begin{tabular}{|c|c|c|c|c|c|c|c|}
\hline \multirow{2}{*}{ Month/year } & \multicolumn{4}{|c|}{ Surf zone } & \multicolumn{3}{|c|}{ Morphodynamics } \\
\hline & $\mathrm{T}\left({ }^{\circ} \mathrm{C}\right)$ & $S$ & $\mathrm{Hb}(\mathrm{cm})$ & $\mathrm{P}(\mathrm{sec})$ & $\operatorname{Md}(\phi)$ & $\Omega$ & $\beta \mathrm{BF}(()$ \\
\hline February 1992 & 26.7 & 30.8 & 60 & 8.0 & 2.85 & 5.1 & 1.29 \\
\hline March & 26.9 & 31.3 & 45 & 9.5 & 2.84 & 3.2 & 0.99 \\
\hline April & 24.9 & 33.2 & 80 & 5.5 & 2.84 & 9.8 & 1.01 \\
\hline May & 23.0 & 32.1 & 75 & 10.7 & 2.92 & 5.2 & 1.07 \\
\hline June & 21.6 & 29.9 & 95 & 6.5 & 2.93 & 10.9 & 1.04 \\
\hline July & 17.0 & 33.0 & 95 & 6.5 & 2.88 & 10.3 & 0.96 \\
\hline September & 20.0 & 30.6 & 75 & 4.2 & 2.86 & 12.4 & 1.04 \\
\hline November & 24.4 & 33.8 & 35 & 10.3 & 2.91 & 2.6 & 0.89 \\
\hline December & 25.8 & 33.4 & 65 & 13.0 & 2.91 & 3.4 & 1.02 \\
\hline January 1993 & 29.2 & 33.5 & 60 & 4.3 & 2.95 & 10.6 & 1.13 \\
\hline February & 28.5 & 33.5 & 65 & 5.0 & 2.99 & 10.3 & 0.98 \\
\hline March & 28.6 & 31.8 & 40 & 6.6 & 2.89 & 4.3 & 0.97 \\
\hline
\end{tabular}

Euzonus furciferus showed a bimodal population structure from May to October, being unimodal in other months (Fig. 4). Recruitment was higher from May to September and with a peak in July, resulted in a presence of two cohorts during this period (Figs 4 and 5). Growth parameters obtained for a sVBGF were $\mathrm{L}_{\infty}=2.32 \mathrm{~mm}, \mathrm{~K}=0.763, \mathrm{C}=1.00, \mathrm{WP}=0.10(\mathrm{Rn}$ $=0.288$ ). The life span was of 1.8 years, and the mortality was 3.20. The relation between body width at chaetiger $8^{\text {th }}(\mathrm{C})$ and ash free dry weight (AFDW) was: $\log _{10}$ AFDW $=2.261 \log _{10} \mathrm{C}-$ $0.0159, \mathrm{r}^{2}=0.425, \mathrm{n}=63, \mathrm{p}<0.005$

The secondary production of Euzonus furciferus was 0.466 gAFDW $\mathrm{m}^{-2} \mathrm{y}^{-1}$, with a mean annual biomass of $0.218 \mathrm{gAFDW} \mathrm{m}^{-2}$, and a P/B ratio of $2.13 \mathrm{y}^{-1}$ (Tab. II).

\section{DISCUSSION}

Other species of opheliids are common in the intertidal of subtropical and temperate sandy beaches around the world, where usually present a well defined zonation. Euzonus heterocirrus Rozbaczylo \& Zamorano, 1985 was found at middle shore on intermediate beaches, in South-central Chile (JARAmillo 1994). Euzonus mucronata Treadwell, 1914 occurred throughout Californian coastline beaches, in areas only reached by high tides. It forms well-defined bands in the upper inter tidal (KeMP 1988), with mean densities varying from 22,957 to 27,548 individuals. $\mathrm{m}^{-2}$, with peaks higher than 36,500 ind. $\mathrm{m}^{-2}$ (McConnaughey \& Fox 1949). Armandia sp., another Opheliid 

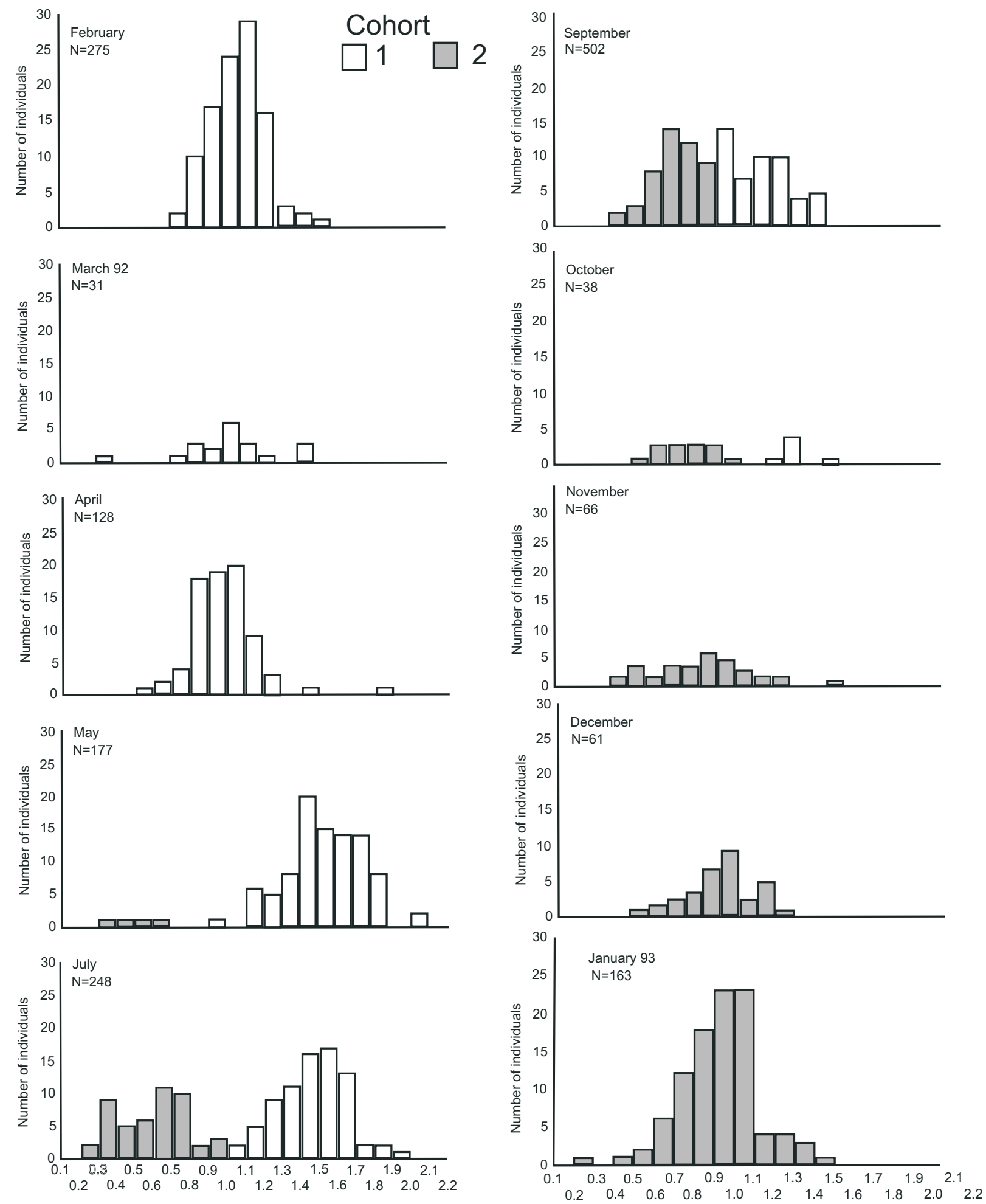

8th Neuropodium width

8th Neuropodium width

Figure 4. Neuropodium size frequency histogram and delineated cohorts for 10 sampling dates of Euzonus furciferus at Atami Beach from February 1992 to March 1993. 


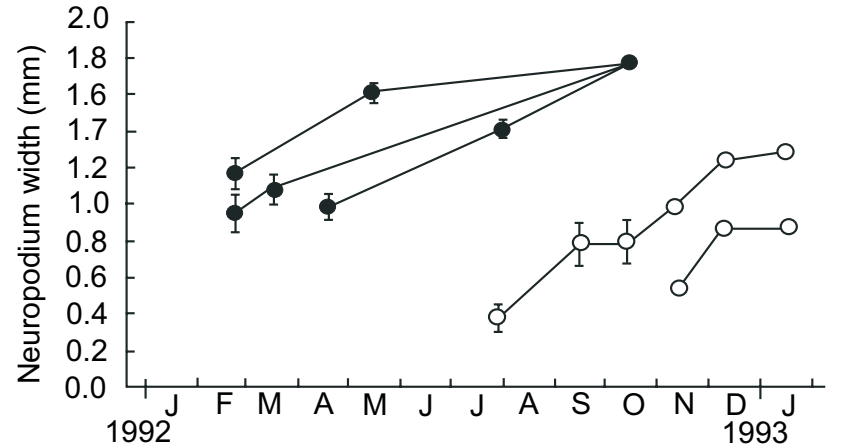

Figure 5. Growth of individual year-classes of Euzonus furciferus at Atami Beach from February 1992 to March 1993. Vertical bars are standard deviations of the normalized expected frequencies.

Table II. Secondary production (P) of Euzonus furciferus in Atami Beach estimated by mass specific growth rate method (MSGR). (Nj) Mean annual number of individuals in class j (no. ind. $\mathrm{m}^{-2}$ ); (Mj) mean individual mass in class j (mgAFDW), obtained by length-weigth relation; $(\mathrm{Gi})$ the corresponding mass-specific growth rate obtained from VBGF parameters, and the size-mass relation.

\begin{tabular}{cccccc}
\hline Mid length $(\mathrm{mm})$ & $\mathrm{Nj}$ & $\mathrm{Mj}$ & Biomass & $\mathrm{Gi}$ & \multicolumn{1}{c}{$\mathrm{P}$} \\
\hline 0.25 & 0.560 & 0.042 & 0.023 & 20.383 & 0.479 \\
0.35 & 2.109 & 0.090 & 0.189 & 13.797 & 2.613 \\
0.45 & 2.735 & 0.158 & 0.433 & 10.138 & 4.394 \\
0.55 & 4.482 & 0.249 & 1.118 & 7.810 & 8.734 \\
0.65 & 9.001 & 0.364 & 3.276 & 6.198 & 20.307 \\
0.75 & 14.208 & 0.503 & 7.148 & 5.016 & 35.851 \\
\hline
\end{tabular}

deposit feeder of intertidal sandy beaches in Japan, were also found in a well defined zone parallel to coast line (TAMAKI 1985).

Euzonus furciferus is the only deposit feeder species in the upper and middle intertidal of South Brazilian sandy beaches. Its presence at Atami Beach may be related to food availability and adaptations to intertidal life. High concentration of saprophytic bacteria in the upper intertidal were found in beaches near Atami Beach (Kolm \& CorrêA 1994). Adaptations to intertidal life were studied for E. mucronata. This species moves throughout the sediment that usually presented daily differences in $\mathrm{O}_{2}$ concentration, salinity and temperature. The presence of abundant hemoglobin in it tissues, more or less $19 \%$ of total dry weight, may suggest the importance of this protein to maintain an aerobic metabolism during low tide (Dangott \& Terwilliger 1986). E. mucronata is also abundant in high energy reflective sandy beaches of the Pacific Coast of North America. In this particular beach type, with low bacteria concentration, direct assimilation of detrital carbon may supply its metabolic requirements (KемP 1986).

Euzonus furciferus were not found in typical reflective beaches with coarse sand of the Paraná littoral (Borzone et al.
1996, BARros et al. 2001). Densities in Atami Beach were similar to those found by GIANUCA (1987) for a population at the dissipative beach of Cassino, in Rio Grande do Sul (South Brazil), with an annual mean of 425 ind. $\mathrm{m}^{-2}$, and peaks of 4,075 ind. $\mathrm{m}^{-2}$ during or just after recruitment periods in spring and summer months. Zonation by size in the distribution along the beach, with largest individuals concentrated in the upper intertidal and juveniles concentrated in the low intertidal, were found for different species of Euzonus (Dales 1952, Gianuca1987, Kemp 1988).

At Atami Beach, Euzonus furciferus grew faster in winter and early spring than in other seasons. Highest summer temperature and/or more food availability during winter (e.g. bacteria in sediment) may explain this different pattern. E. mucronata grew faster in spring to fall on Oregon beaches, but little or no growth occurred in winter, where lowest temperature reach approximately $2^{\circ} \mathrm{C}\left(44^{\circ} \mathrm{N}\right)$ (Kemp 1988).

Reproductive season at Atami Beach extended from January to August (summer to winter), and was different and larger than those presented by the same species at Cassino Beach, form September to March (spring to summer) (Gianuca 1987). Reprodutive period seems to be shorter in higher latitudes than in lower latitudes, for example E. mucronata recruits from spring to summer in South California (McConnaughey \& Fox 1949) but recruitment occurred in one or two months in Oregon (KEMP 1988).

Annual secondary production estimated for Euzonus furciferus was similar to that estimated to the filter-feeder spionid Scolelepis squamata (OF Müller, 1789) at the same beach (SouzA $\&$ Borzone 2000), but ten times lower than the annual production estimated for E. mucronata in Pacific sandy beaches $\left(44.6^{\circ} \mathrm{N}\right)$, with a mean biomass of $2.5 \mathrm{gAFDW} \mathrm{m}^{-2}$ and second-

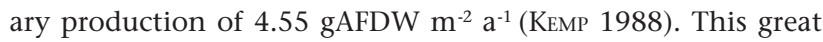
differences, also found when compared other sandy beach spionid species (Souza \& Borzone 2000), may indicate that general food disposability of each beach environment is more important for production than the trophic strategic adopted by those organisms exploring this environment.

\section{REFERENCES}

Barros Jr, F.C.R.; C.A. Borzone \& S. Rosso. 2001. The Macroinfauna of six beaches near Guaratuba Bay, Southern Brazil. Brazilian Archives of Biology and Technology 44 (4): 351-364.

Bhattacharya, C.G. 1967. A simple method of resolution of a distribution into Gaussian components. Biometrics 23: 115135.

Borzone, C.A. \& J.R.B. SouzA. 1997. Estrutura da macrofauna Bentônica no supra, meso e infralitoral de uma praia arenosa do sul do Brasil. Oecologia Brasiliensis 3: 197-212.

Borzone, C.A.; J.R.B. Souza \& A.G. SoAres. 1996. Morphodynamic influence on the structure of inter and subtidal macrofaunal communities of subtropical sandy beaches. Revista Chilena de História Natural 69: 565-577.

CRISP, D.J. 1984. Energy flow measurements, p. 197-279. In: N.A.

Revista Brasileira de Zoologia 24 (4): 1139-1144, dezembro 2007 
Holme \& A.D. McIntyre (Eds). Methods for the study of marine benthos. Oxford, Blackwell, 387p.

Dales, R.P. 1952. The larval development and ecology of Thoracophelia mucronata (Treadwell). Biological Bulletin 102: 232242.

Dangott, L.J. \& R. C. Terwilliger. 1986. The role of extracellular hemoglobins in the oxigen consumption of the burrowing polychaete, Euzonus mucronata (Treadwell). Journal of Experimental Marine Biology and Ecology 97: 193-204.

Defeo, O.; E. Jaramillo, \& A. Lyonnet. 1992. Community structure and intertidal zonation of the macroinfauna on the Atlantic coast of Uruguai. Journal of Coastal Research 8 (4): 830839.

Escofet, A.; N.M. Gianuca; S. Maytia \& V. Scarabino. 1979. Playas arenosas del Atlantico Sudoccidental entre los $29^{\circ}$ y $43^{\circ} \mathrm{LS}$ : consideraciones generales y esquema biocenologico, p. 245258. In: UNESCo (Ed.). Memorias del Seminario sobre ecologia bentonita y sedimentación de la plataforma continental del Atlantico Sur. Montevideo, Unesco, 280p.

FAuchald, K. \& P.A. Jumars. 1979. The diet of worms: A study of polychaete feeding guilds. Oceanography and Marine Biology 17: 193-284.

Gayanilo Jr, F.C.; P. Sparre \& D. Pauly. 1996. The FAO-IClarm stock assessment tools (FISAT) user's guide. Rome, FAO Computerized Information Series, Fisheries, no. 8, 126p.

GianUCA, N.M. 1987. Zonação e produção nas praias arenosas do litoral sul e sudeste do Brasil: Síntese dos conhecimentos. ACIESP 54 (1): 313-332.

Jaramillo, E. 1994. Patterns of species richness in sandy beaches of South America. South African Journal of Zoology 29 (4): 227-234.

KEMP, P.F. 1986. Deposition of organic matter on a high energy sand beach by a mass stranding of the cnidarian Velella velella (L.) Estuarine, Coastal and Shelf Science 23: 575-579.

Kemp, P.F. 1988. Production and life history of a deposit feeding polychaete in an atypical environment. Estuarine, Coastal and Shelf Science 26 (4): 437-446.

Kolm, H.E. \& M.F. CoRreA. 1994. Distribuição espacial e variabilidade temporal de bacterias saprofitas na praia arenosa de Pontal do Sul, Paraná. Brazilian Archives of Biology and Technology 37 (2): 391-402.

Received in 23.VII.2007; accepted in 27.XI.2007.
Masselink, G. \& A.D. Short. 1993. The effect of tide range on beach morphodynamics and morphology: a conceptual beach model. Journal of Coastal Research 9 (3): 785-800.

McConnaughey B.H. \& D.L. Fox. 1949. The anatomy and biology of the marine Polychaete Thoracophelia mucronata (Treadwell) Opheliidae. University of California Publications in Zoology 47 (12): 319-340.

McLachlan A. \& A.C.Brown. 2006. The ecology of sandy shores. San Diego, Academic Press, 373p.

Orensanz, J.M. \& N.M. Gianuca. 1974. Contribuição ao conhecimento dos anelídeos poliquetas do Rio Grande do Sul, Brasil. I - Lista sistemática preliminar e descrição de três novas espécies. Comunicação do Museu de Ciências PUCRGS 4: 1-37.

PAULY, D. 1986. On improving operation and use of the ELEFAN programs. Part II. Improving the estimation of $\mathrm{L}_{\infty}$. ICLARM Fishbyte 4 (1): 18-20.

Pauly, D. \& G. Gaschutz. 1979. A simple method for fitting oscillating length growth data, with a program for pocket calculators. ICES. CM 1979/G: 24. Copenhagen, Demersal Fish Committee, 26p.

Santos, C.S.G.; E.F. Nonato \& M.E. Petersen. 2004. Two new species of Opheliidae (Annelida, Polychaeta), Euzonus papillatus sp. n. from a northeastern Brazilian sandy beach and Euzonus mammillatus sp. n. from the continental shelf of south-eastern Brazil. Zootaxa 478: 1-12.

SouzA, J.R.B \& C.A. Borzone. 2000. Population dynamics and secondary production of Scolelepis squamata (Polychaeta: Spionidae) in an exposed sandy beach of southern Brazil. Bulletin of Marine Science 67 (1): 221-233.

SouzA, J.R.B. \& N.M.GianucA. 1995. Zonation and seasonal variation of the intertidal macrofauna on a sandy beach of Parana state, Brazil. Scientia Marina 59: 103-111.

TAMAKI, A. 1985. Zonation by size in the Armandia sp. (Polychaeta: Ophaeliidae) population on an intertidal sand flat. Marine Ecology Progress Series 27: 123-133.

TANnER, W.F. 1995. Environmental clastic granulometry. Tallahasse, Florida Geological Survey, Special Publication, no. $40,146 \mathrm{p}$.

Wetherall, J.A. 1986. A new method for estimating growth and mortality parameters from length-frequency data. ICLARM Fishbyte 4: 12-14. 